\title{
Calcium Oxalate Crystal Adherence to Hyaluronan-, Osteopontin-, and CD44-Expressing Injured/Regenerating Tubular Epithelial Cells in Rat Kidneys
}

\author{
MARINO ASSELMAN, * ANJA VERHULST, ${ }^{\dagger}$ MARC E. DE BROE, ${ }^{\dagger}$ and \\ CARL F. VERKOELEN* \\ *Department of Urology, Erasmus Medical Center Rotterdam, Rotterdam, the Netherlands; and ${ }^{\dagger}$ Department \\ of Nephrology-Hypertension, University of Antwerp, Antwerp, Belgium
}

\begin{abstract}
Retention of crystals in the kidney is an essential early step in renal stone formation. Studies with renal tubular cells in culture indicate that hyaluronan (HA) and osteopontin (OPN) and their mutual cell surface receptor CD44 play an important role in calcium oxalate $(\mathrm{CaOx})$ crystal binding during wound healing. This concept was investigated in vivo by treating rats for 1,4 , and $8 \mathrm{~d}$ with ethylene glycol $(0.5$ and $0.75 \%$ ) in their drinking water to induce renal tubular cell damage and $\mathrm{CaOx}$ crystalluria. Tubular injury was morphologically scored on periodic acid-Schiff-stained renal tissue sections and tissue repair assessed by immunohistochemical staining for proliferating cell nuclear antigen. $\mathrm{CaOx}$ crystals were visualized in periodic acid-Schiff-stained sections by polarized light microscopy, and renal calcium deposits were quantified
\end{abstract}

with von Kossa staining. HA was visualized with HA-binding protein and OPN and CD44 immunohistochemically with specific antibodies and quantified with an image analyzer system. Already after $1 \mathrm{~d}$ of treatment, both concentrations of ethylene glycol induced hyperoxaluria and $\mathrm{CaOx}$ crystalluria. At this point, there was neither tubular injury nor crystal retention in the kidney, and expression of HA, OPN, and CD44 was comparable to untreated controls. After 4 and $8 \mathrm{~d}$ of ethylene glycol, however, intratubular crystals were found adhered to injured/regenerating (proliferating cell nuclear antigen positive) tubular epithelial cells, expressing HA, OPN, and CD44 at their luminal membrane. In conclusion, the expression of HA, OPN, and CD44 by injured/regenerating tubular cells seems to play a role in retention of crystals in the rat kidney.
The development of kidney stones requires formation of crystals followed by their retention in the kidney (1). Crystal retention could be caused by adherence of crystals to the epithelial cells lining the renal tubules (2). Although many investigators recognized a role for renal tubular injury in the pathophysiology of nephrolithiasis, definite proof for this concept and the mechanisms involved are not yet available (3-7).

Most kidney stones are predominantly composed of precipitated calcium salts, the most common of which is calcium oxalate monohydrate (5). Studies with renal tubular epithelial cells in culture showed that confluent monolayers of distal tubule/collecting duct-like MDCK-I cells are nonadherent to calcium oxalate monohydrate crystals (8). In contrast, crystals bind to cells in subconfluent cultures and in confluent monolayers recovering from mechanical injury (9). The glycosaminoglycan hyaluronan (HA) was identified as a major crystal-

Received April 22, 2003. Accepted September 7, 2003.

Correspondence to Dr. Marc E. de Broe, University of Antwerp, Department of Nephrology-Hypertension, p/a University Hospital Antwerp, Wilrijkstraat 10, B-2650 Edegem/Antwerpen, Belgium; Phone: +32-3-821-3421; Fax: +32-3-829-0100; E-mail: debroe@uia.ua.ac.be

M.A. and A.V. contributed equally to this work.

1046-6673/1412-3155

Journal of the American Society of Nephrology

Copyright (C) 2003 by the American Society of Nephrology

DOI: 10.1097/01.ASN.0000099380.18995.F7 binding molecule at the surface of MDCK-I cells (10) and of human renal tubular cells in primary culture (11). In addition, it was found that crystal-binding cells not only expressed HA at their apical surface but also osteopontin (OPN) and CD44 (11).

$\mathrm{HA}$ is a high molecular mass polysaccharide $\left(>10^{6} \mathrm{Da}\right)$, composed of linear polymers of a repeating disaccharide structure of alternating glucuronic acid and $\mathrm{N}$-acetylglucosamine. In the kidney, HA is hardly detectable in the cortex but is abundantly present as the main component of the renal inner medullary interstitium (12). HA in the kidney is upregulated during various inflammatory disease states (13-17). OPN is a glycoprotein and is widely spread throughout organs and tissues, including the kidney. In the healthy kidney, OPN is confined to the distal parts of a subset of nephrons. During various types of inflammation, however, renal OPN is severely upregulated in most segments of the nephron $(13,14,18-20)$. The transmembrane protein CD44 is a cell surface receptor for both HA and OPN $(21,22)$ and also is upregulated during inflammation in the kidney $(13,14)$. The present study was conducted to investigate whether in vivo renal tubular injury and HA, OPN, and CD44 expression are involved in crystal retention.

\section{Materials and Methods \\ Experimental Design}

Male Wistar rats (300 to $350 \mathrm{~g}$ ) were obtained from the Central Animal Breeding Center (Harlan, Zeist, the Netherlands) and divided into three groups $(n=9$ each) receiving drinking water supplemented 
with $0,0.5$, or $0.75 \%$ (vol/vol) ethylene glycol (EG) for 1,4 , and $8 \mathrm{~d}$. All animals had free access to standard chow. Twenty-four hours before the indicated times, rats were housed individually in metabolic cages to collect 24-h urine samples and to monitor fluid intake. Urine samples were divided into portions of $5 \mathrm{ml}$, one portion of which was acidified with $100 \mu \mathrm{l}$ of $1 \mathrm{M}$ hydrochloric acid and stored at $-20^{\circ} \mathrm{C}$ until analysis. Animals were sedated and killed; kidneys were extracted and decapsulated; and sagittal slices were immediately fixed in either methacarn (60\% methanol, $30 \%$ chloroform, $10 \%$ acetic acid) or Dubosq-Brasil fixative (47\% ethanol, $11.7 \% \mathrm{H}_{2} \mathrm{O}, 23.5 \%$ formaldehyde, $17.6 \%$ acetic acid, and $4 \mathrm{mM}$ picric acid) for $4 \mathrm{~h}$, rinsed with $70 \%$ ethanol, and embedded in low-melting-point paraffin $\left(52^{\circ} \mathrm{C}\right.$; BDH Laboratory Supplies, Poole, UK). Serum specimens were collected and frozen at $-20^{\circ} \mathrm{C}$ until biochemical analysis. The experiments were approved by the local University Animal Committee and carried out in accordance with the Netherlands Experiments on Animals Act (1977) and the European Convention for the Protection of Vertebrate Animals Used for Experimental Purposes (Strasbourg, March 18, 1986).

\section{Urine and Serum Biochemistry}

Urinary oxalate was determined in acidified urine portions with a quantitative enzymatic colorimetric assay (Sigma Diagnostics, Deisenhofen, Germany). For determination of urinary citrate, the ultraviolet method with the test combination of Boehringer Mannheim (Darmstadt, Germany) was used. The concentrations of calcium in urine and bicarbonate, calcium, and creatinine in serum were determined on a routine autoanalyzer system (Vitros $750 \mathrm{XRC}$ ). Urine samples were centrifuged at $5000 \times g$, and sediments were inspected by optical and polarized light microscopy (Zeiss Axioplan microscope, Oberkochen, Germany).

\section{Tubular Morphology}

Methacarn-fixed, paraffin-embedded renal tissue sections $(4 \mu \mathrm{m})$ were stained with periodic acid-Schiff (PAS), and nuclei were counterstained with methyl green. Histologic damage was evaluated with a morphologic scoring system (Table 1) in proximal tubules (PT), thin limbs of Henle (TLH), distal tubules (DT; including thick ascending limbs [TAL]) and collecting ducts (CD). Tubules were morphologically inspected by a reproducible procedure, which comprised a random selection of the first tubular cross-section, followed by shifting the microscopic field over fixed distances according to a standardized pattern $(\times 300$ magnification). The cortex, outer stripe of the outer medulla (OSOM), inner stripe of the outer medulla (ISOM), and inner medulla of each kidney section were evaluated. In the cortex, PT (S1-S2) and DT were evaluated ( $n=50$ and 25, respectively); in the OSOM, PT (S3) and DT (TAL) were evaluated $(n=50$ and 25 , respectively); in the ISOM, TLH and DT (TAL) were evaluated ( $n=$ 25 each); and in the inner medulla, TLH and CD were evaluated ( $n=$ 25 each). PT and DT could be distinguished according to at least one of the following morphologic criteria: topographical localization, tubular size and form, cytoplasmic density and position of the nuclei, and presence or absence of brush border and basolateral cell aspect. Tubules in the cortex and OSOM were scored as PT only when a brush border could be identified; if not, then they were scored as DT. In the ISOM and inner medulla, TLH could be distinguished from DT (TAL) and CD by tubular size and position of the nuclei.

Proliferation was determined by immunohistochemical staining for proliferating cell nuclear antigen (PCNA) using the PC10 mAb (DAKO, Glostrup, Denmark) as described previously (23). Routinely, sections were counterstained with PAS and nuclei were stained with methyl green. In a number of sections, PAS staining was omitted, allowing optimal visualization of crystals. Expression of PCNA was quantified morphometrically with an image analyzer system (KS-400 V2.0 image analysis software) in the cortex + OSOM and ISOM + inner medulla, by measuring positive signals in 25 and 15 randomly chosen microscopic fields, respectively ( $\times 250$ magnification). Measurements were expressed as fractional positive area of the tissue section.

\section{Crystal Retention}

During the evaluation of tubular morphology, each tubule was additionally inspected by polarized light microscopy for the presence of crystals. In this way, crystal retention was assessed and sites of crystal location were correlated with tubular morphology.

Calcium deposits were also visualized by von Kossa staining. Deparaffinized Dubosq-Brasil-fixed 4- $\mu \mathrm{m}$ tissue sections were incubated in 5\% silver nitrate for $45 \mathrm{~min}$. Slides were rinsed in water, incubated in $1 \%$ pyrogallic acid for $3 \mathrm{~min}$, rinsed in water, fixed in $5 \%$ sodium thiosulfate for $1 \mathrm{~min}$, and counterstained with hematoxylin and eosin. In each sagittal kidney section, calcium deposits were quantified by counting the total number of positive stained crystals in the cortex + OSOM and ISOM + inner medulla.

\section{HA, OPN, and CD44 Expression}

Renal tissue sections were stained for HA, OPN, and CD44 as described previously (11). Briefly, methacarn-fixed tissue sections were blocked with $1 \%$ BSA for HA and with normal horse serum for OPN and CD44 staining and incubated with primary labels (biotinylated HA-binding protein, Seikagaku, Falmouth, MD; goat antihuman OPN antibody, OP189, C.M. Giachelli, University of Washington; or mouse anti-human CD44 antibody, Bender MedSystems, Vienna, Austria). For OPN and CD44, sections were subsequently incubated with secondary labels, biotinylated horse anti-goat and horse anti-mouse antibodies (Vector Laboratories, Burlingame, CA), respectively. Finally, avidin-biotin peroxidase complex (Vector) and diaminobenzidine were used to detect HA, OPN, and CD44. Sections were counterstained with methyl green. No staining was observed when primary labels were omitted.

Table 1. Scoring system for the evaluation of tubular morphology of PT, TLH, DT (including TAL), and CD

\begin{tabular}{clll}
\hline Score & \multicolumn{1}{c}{ PT } & \multicolumn{1}{c}{ TLH } & \multicolumn{1}{c}{ DT (TAL)/CD } \\
\hline 0 & Intact tubule with normal appearance & Intact tubule with normal appearance & Intact tubule with normal appearance \\
1 & Tubule with luminal cell debris & Tubule with luminal cell debris & Tubule with luminal cell debris \\
2 & Tubule with loss of brush border & - & Dilated tubule \\
3 & Tubule with flattened cells & - & Tubule with flattened cells \\
\hline
\end{tabular}

${ }^{\text {a }}$ PT, proximal tubules; TLH, thin limbs of Henle; DT, distal tubules; TAL, thick ascending limbs; CD, collecting ducts. 
Urinary Oxalate Excretion (mg/24h)
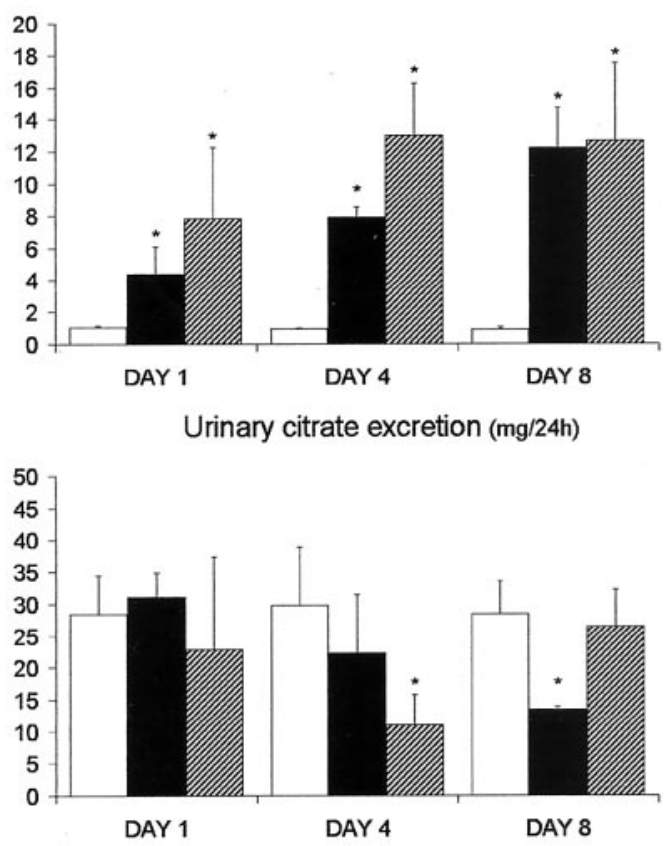

Serum calcium (mg/dl)

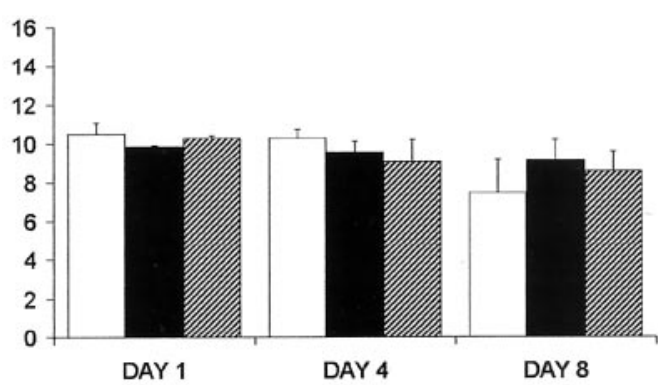

Urine production $(\mathrm{ml} / 24 \mathrm{~h})$

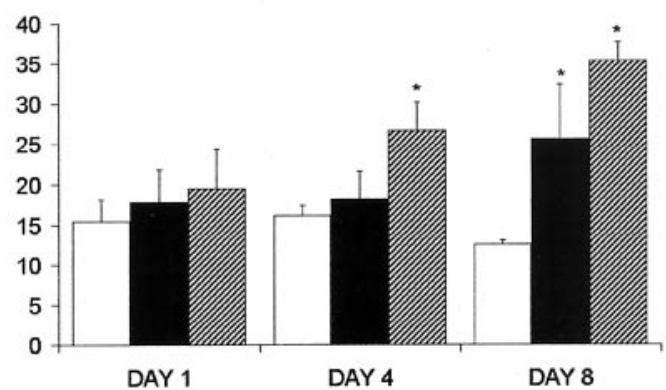

Urinary Calcium Excretion (mg/24h)
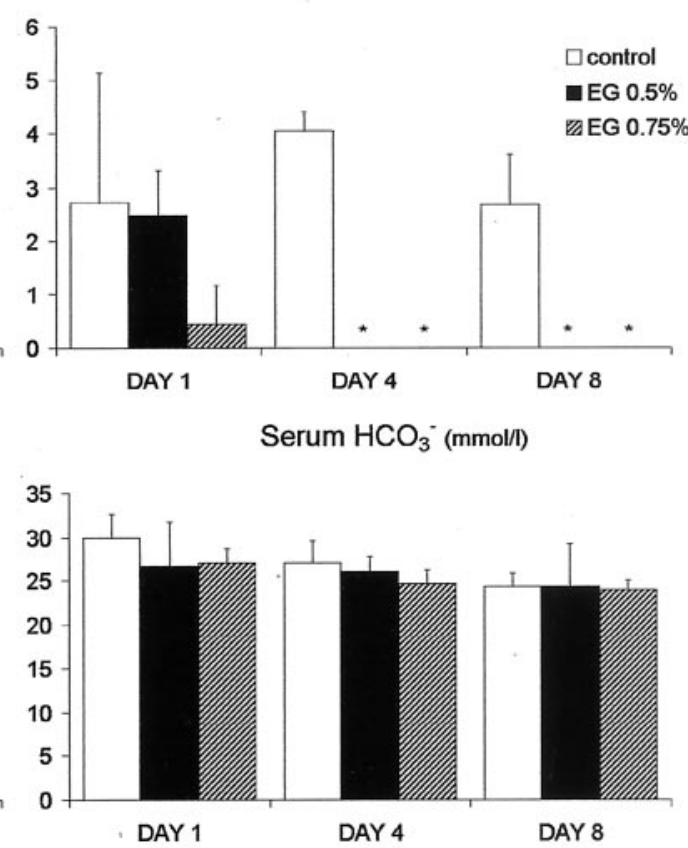

Serum creatinine (mg/dl)

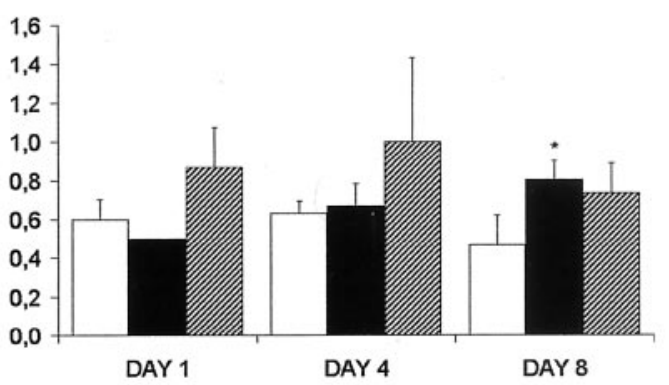

Fluid intake (ml/24h)

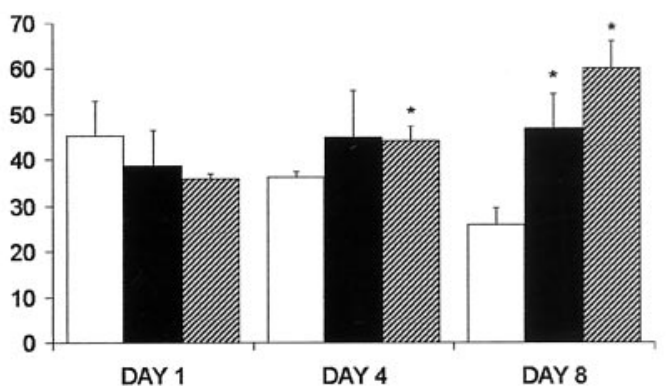

Figure 1. Urine- and serum biochemical analysis, urine production, and fluid intake. Statistical analysis by $t$ test. *Significantly different compared with controls at the same point in time $(P<0.05)$.

Expression of HA, OPN, and CD44 was quantified morphometrically with KS-400 V2.0 image analysis software in the cortex and OSOM, by measuring positive signals in 10 and six randomly chosen microscopic fields, respectively ( $× 200$ magnification). Measurements were expressed as fractional positive area of the tissue section. OPN and CD44 were also quantified in the remaining part of the medulla, by analyzing six randomly chosen microscopic fields of the ISOM and inner medulla. HA was not quantified in this region, because the well known abundant amount of HA in the interstitium of the inner medulla stains nearly the entire tissue (12).

\section{Statistical Analyses}

Data are expressed as mean \pm SEM. $P<0.05$ was considered to be significant, using $t$ test. Correlation analysis between total tubular PCNA expression per sagittal kidney section and the total amount of 

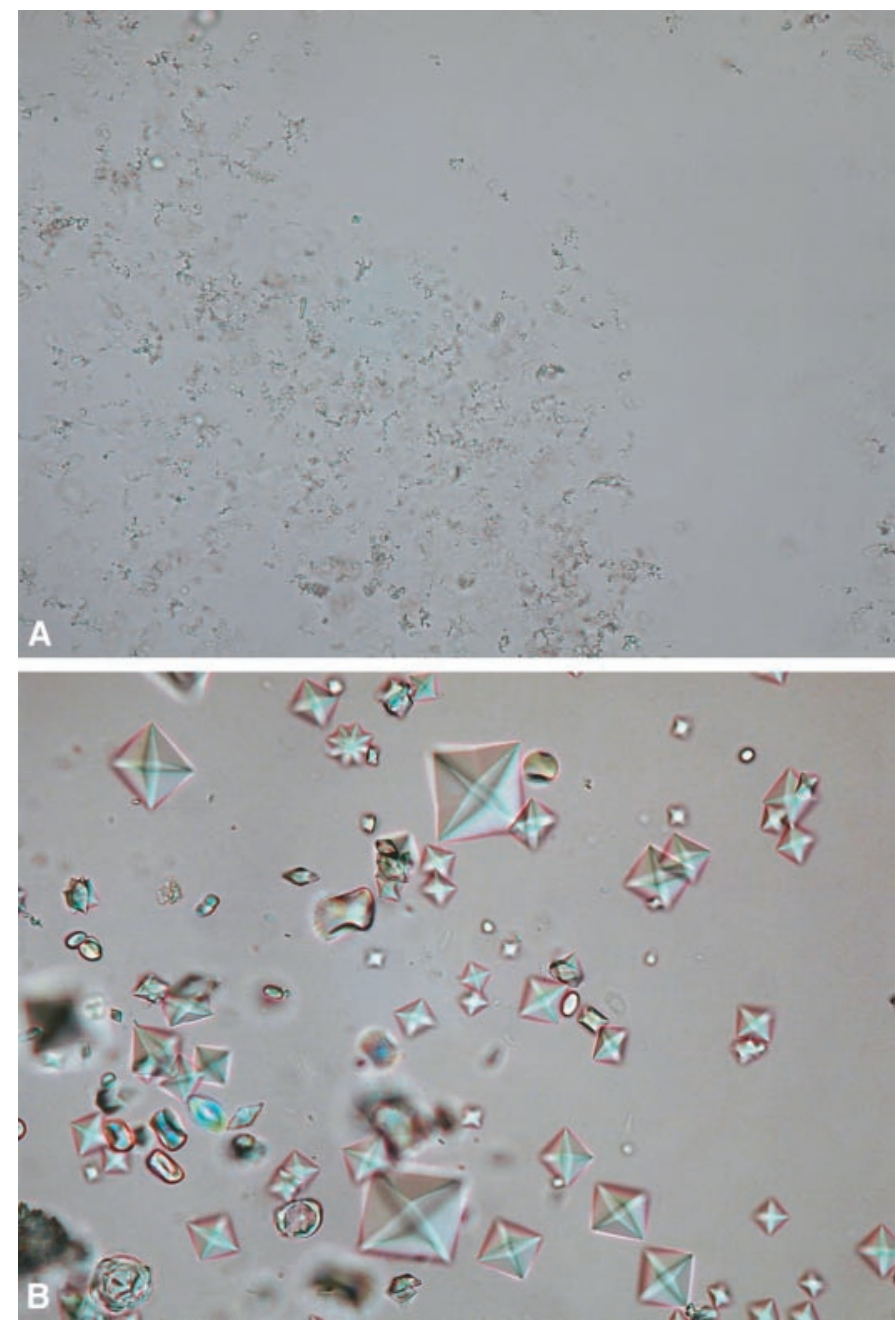

Figure 2. Urinary sediment inspected by polarized light microscopy of a control rat (A) and a $0.5 \%$ ethylene glycol (EG)-treated rat (B) after 1 d. (A) Some debris was observed, but no urinary crystalline material. (B) Numerous urinary calcium oxalate crystals in the EG-treated rat are clearly visible. Magnification, $\times 400$.

positive von Kossa renal calcium deposits per sagittal kidney section in individual rats was performed by the nonparametric Spearman's rank order test. $P<0.01$ was considered significant (two-tailed). Computations were performed using SPSS version 10.

\section{Results}

\section{Urine and Serum Biochemistry}

In the control group, the average urinary oxalate and calcium excretion was $0.95 \pm 0.05$ and $3.24 \pm 0.79 \mathrm{mg} / 24 \mathrm{~h}$, respectively (Figure 1), and the urinary sediment did not contain crystals (Figure 2A). Administration of 0.5 and $0.75 \%$ EG to the drinking water induced within $24 \mathrm{~h}$ a significant concentration-dependent hyperoxaluria $(4.37 \pm 1.71$ and $7.78 \pm 4.46$ $\mathrm{mg} / 24 \mathrm{~h}$, respectively). In the $0.5 \%$ EG group, oxalate gradually increased further to reach its maximum level at day 8 , whereas in the $0.75 \%$ EG group, urinary oxalate reached its maximum level already at day 4 . Urinary calcium was decreased at day 1 and was undetectable at day 4 and day 8
(Figure 1). At day 1, calcium oxalate crystals were observed in urinary sediments of both EG groups (Figure 2B). Oxalate was determined in acidified urine portions, which dissolves crystals and therefore represents the total amount of oxalate, including oxalate precipitated with calcium. Because calcium was determined in urine that was not acidified, it represents the amount of free calcium ions. Thus, the decreased amounts of urinary calcium apparently resulted from the formation of $\mathrm{CaOx}$ crystals.

In the $0.5 \%$ EG group at day 8 and in the $0.75 \%$ EG group at days 4 and 8 , increased diuresis and fluid intake were observed compared with controls. Thus, the addition of EG led to polyuria, which may be secondary to the osmotic effect of EG excreted in the urine unchanged (24) or simply because these rats drank more water (Figure 1). There was no increase in serum creatinine, except for a slight increase in the low-dose EG at day 8, indicating that renal function was preserved in these rats. These biochemistry data are in accordance with earlier observations in rats treated with EG (25).

EG caused a metabolic acidosis, as can be derived from the concentration-dependent decrease in urinary citrate after $4 \mathrm{~d}$. This metabolic acidosis was relatively mild, however, as serum bicarbonate and calcium were not affected and a compensatory homeostatic response seemed to normalize urinary citrate after continued EG challenge (Figure 1).

\section{Tubular Morphology}

The relatively low concentrations of EG in the present study did not result in frank necrosis but in mild changes in tubular morphology. At day 1, tubular morphology was comparable to controls, but at days 4 and 8 , different degrees of injury/ regeneration were found in tubules (Figure 3). PT of the OSOM (S3) and, to a lesser extent, PT in the cortex (S1-S2) suffered the most morphologic damage, for the most part with loss of brush border (score 2). Tubules with flattened cells (score 3) were also observed, predominantly in DT (TAL) of the OSOM. Because a tubule with flattened cells was scored only as PT if there was still brush border recognizable, the number of PT with score 3 could actually have been higher. In TLH and CD at days 4 and 8 , increased amounts of luminal cell debris (score 1) were observed, but the majority of these tubules had a normal morphology (score 0). Importantly, cell debris in the tubular lumen in the distal nephron could also have been derived from an "upstream" section of the nephron, and the tubule concerned could actually have been completely healthy.

At day 1, PCNA staining was comparable to control kidneys, in which tubular expression of this protein was sparse (Figure 4A), whereas at days 4 and 8, PCNA staining was clearly upregulated in tubules in rats that received EG (Figure 4B).

\section{Crystal Retention}

No crystals were found in control rat kidneys (Figure 5). After $1 \mathrm{~d}$ of 0.5 and $0.75 \%$ EG, no crystals were observed by polarized light microscopy, consistent with a marginal amount of positive von Kossa signals. At days 4 and 8, however, an increasing number of crystals were found attached to the luminal membrane of tubular epithelial cells, corresponding with a markedly increased number of positive von Kossa signals 


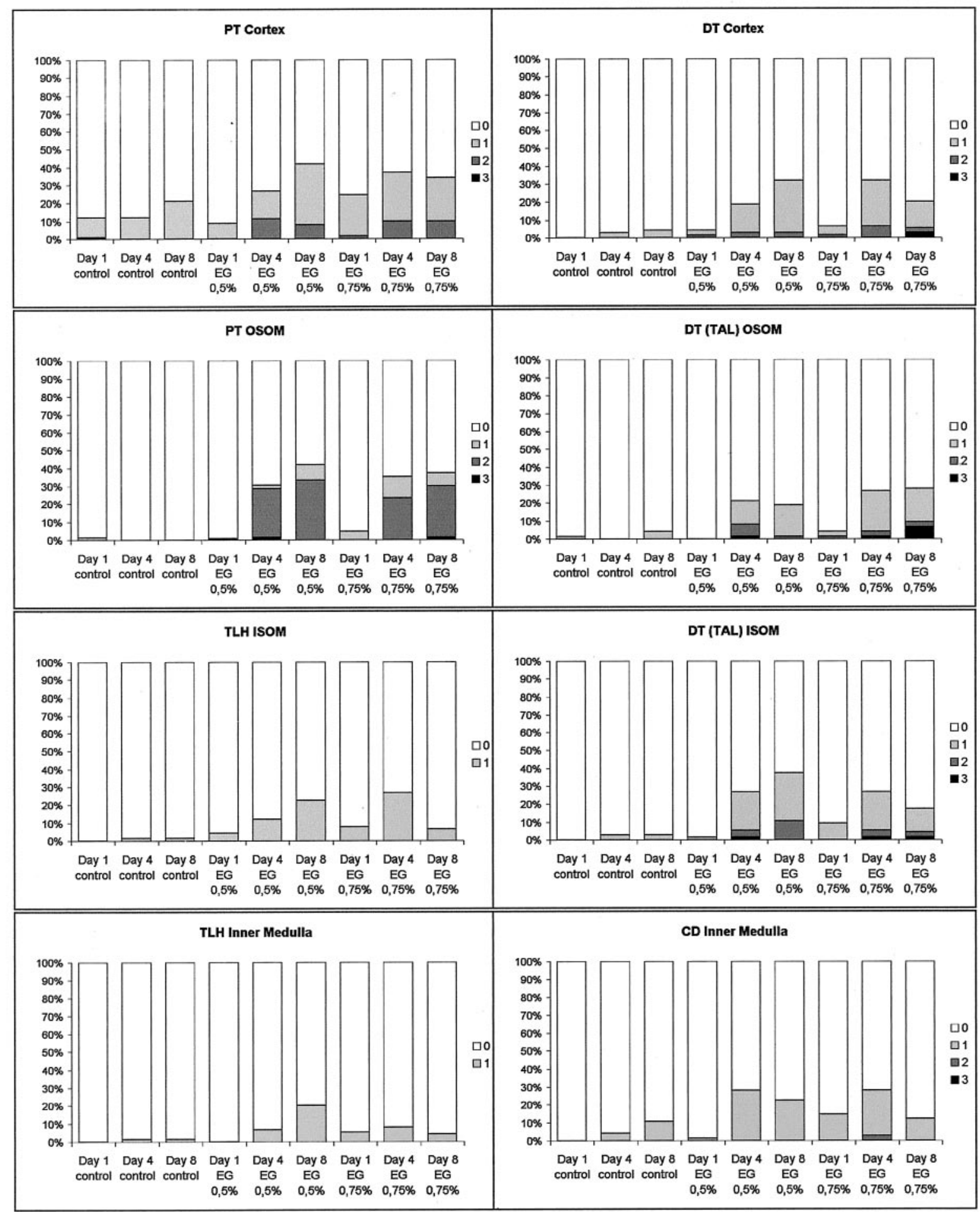

Figure 3. Evaluation of tubular morphology with the scoring system of Table 1 in proximal tubules (PT), thin limbs of Henle (TLH), distal tubules (DT; including thick ascending limbs [TAL]), and collecting ducts (CD $0=$ intact tubule with normal appearance, $1=$ tubule with luminal cell debris, 2 = PT: tubule with loss of brush border/DT (TAL) and CD: dilated tubule, $3=$ tubule with flattened cells).

(Figure 5). Crystals were smaller in size than the tubular lumen and not seen intracellularly or in the interstitium.

In Figure 6, retention of crystals and tubular morphology is plotted in a graph. In PT, DT (TAL), and CD, crystals were not observed in histologic normal tubules (score 0) or tubules with luminal cell debris (score 1). Crystals were found adhered to tubular cells in PT with loss of brush border and DT (TAL) and CD with dilation of the tubular lumen (score 2), and in tubules with flattened cells (score 3 ). Crystals were not observed in TLH (data not shown). Figure 

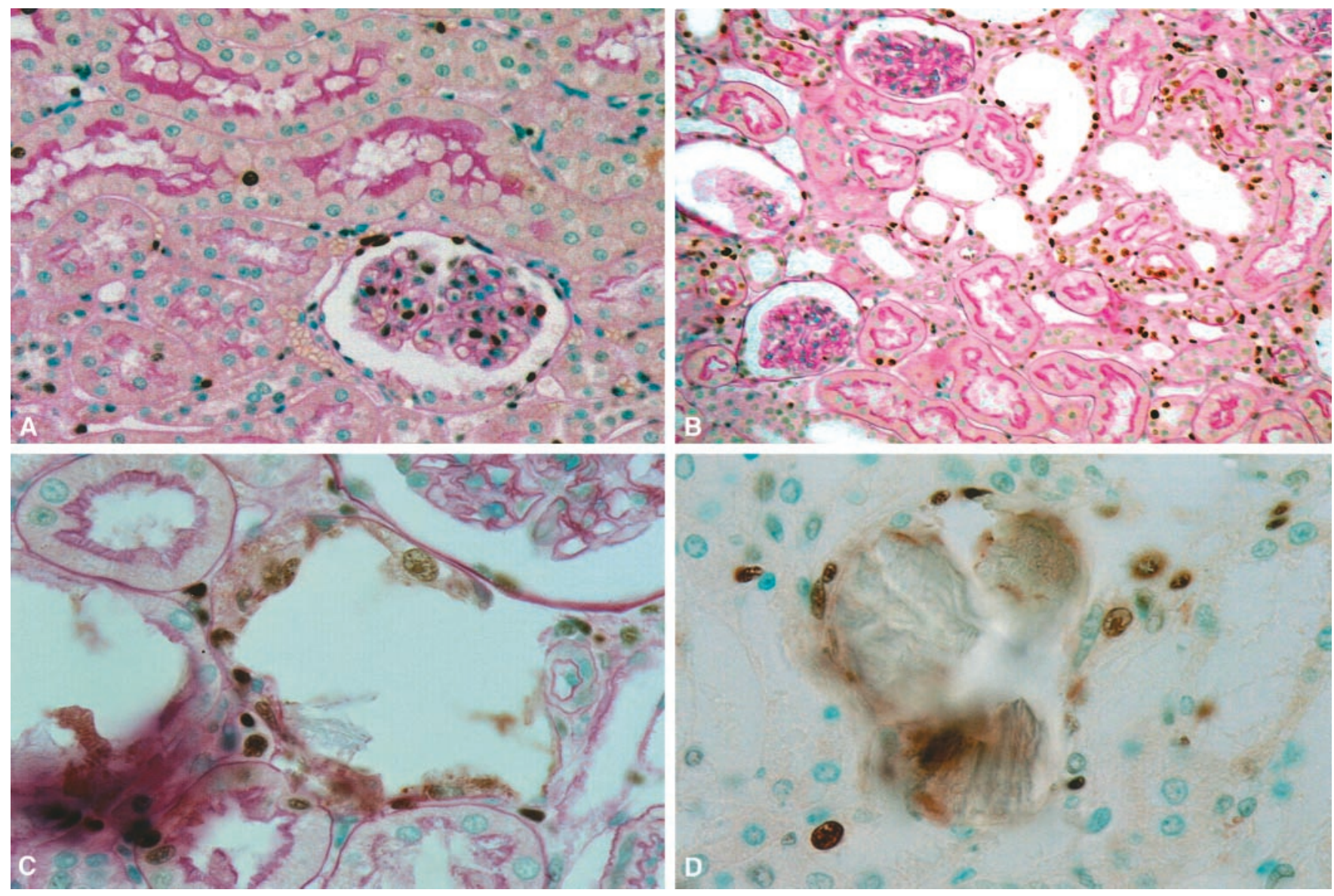

Figure 4. Proliferating cell nuclear antigen (PCNA) staining in a kidney of a control rat (A) and of a rat that received $0.75 \%$ EG for $8 \mathrm{~d}$ (B through D). In D, periodic acid-Schiff (PAS) counterstaining was omitted. (A) Sparse PCNA staining, mainly present in the interstitium and glomeruli in a control rat. (B) Strongly upregulated PCNA in the tubules of an EG-treated rat. (C and D) Crystals associated with PCNA-positive, flattened cells. Magnifications: $\times 400$ in A, $\times 200$ in B, $\times 630$ in C and D.

Cortex + OSOM

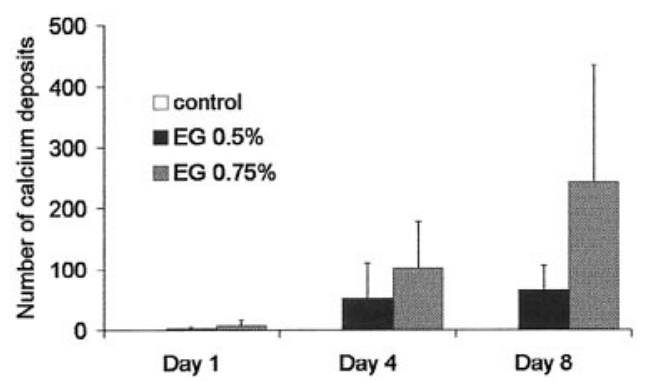

$\mathrm{ISOM}+\mathrm{IM}$

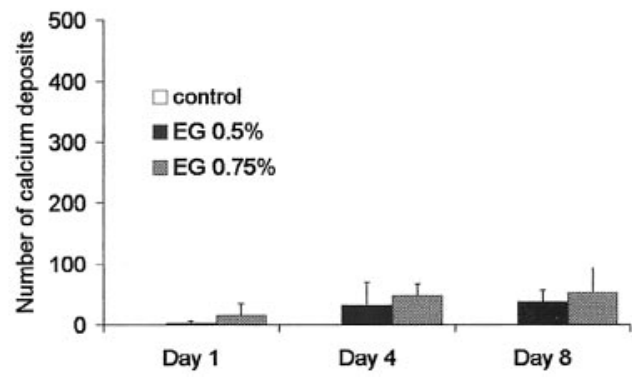

Figure 5. Quantification of renal calcium deposits on von Kossa-stained tissue sections.

7 shows a DT with small crystals at the luminal membrane of flattened tubular epithelial cells (score 3). Furthermore, these flattened cells were PCNA positive, proliferating cells (Figure 4, C and D). Approximately 93\% of the observed crystals in PCNA-stained renal tissue sections were found to be adhered to PCNA-positive cells.

Correlation analysis was performed between the total amount of tubular PCNA expression and the amount of posi- tive von Kossa calcium deposits in sagittal kidney sections of individual rats (Figure 8). Tubular cell regeneration was associated with crystal adhesion/retention (Spearman's Rho = $0.819 ; P<0.0001)$.

\section{HA, OPN, and CD44 Expression}

HA in the cortex and OSOM of control rats was scarcely observed in the interstitium and around a few glomerular 
Proximal tubules

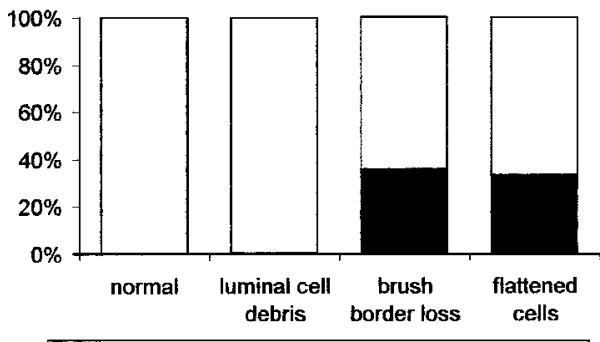

\% tubules with crystals $\square \%$ tubules without crystals
Distal tubules and collecting ducts

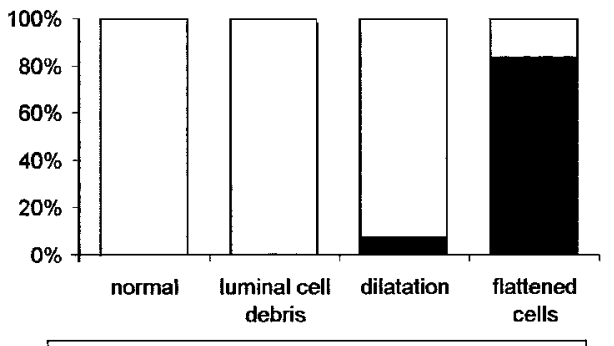

\% tubules with crystals $\square \%$ tubules without crystals

Figure 6. Retention of crystals in relation to tubular morphology. In PT, DT (including TAL), and CD, crystals were not observed in tubules with score 0 (normal appearance) or score 1 (luminal cell debris). Crystals were exclusively retained at the luminal surface of tubular cells in PT, DT, and CD with score 2 (loss of brush border in PT and dilated tubules in DT and CD) and score 3 (tubules with flattened cells).
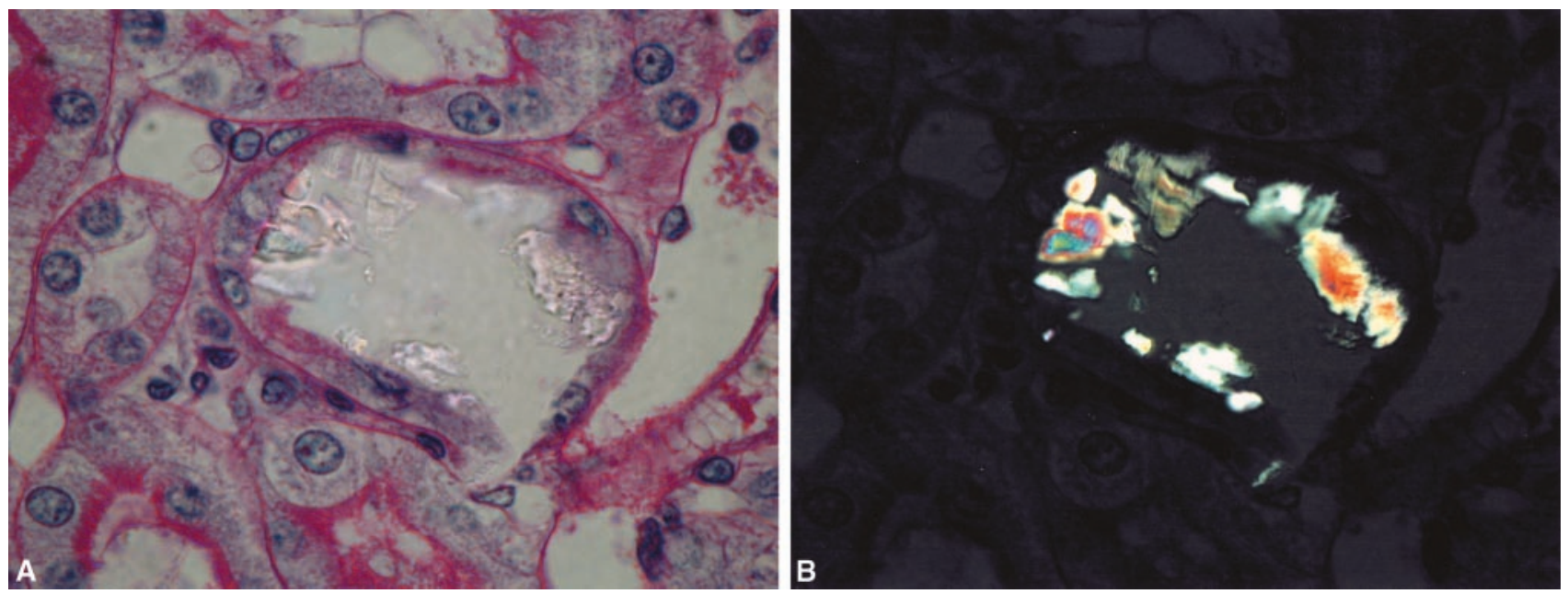

Figure 7. PAS and methyl green-stained renal tissue section of a rat treated with $0.75 \%$ EG for 4 d by optical (A) or polarized (B) light microscopy. (A) A dilated DT is shown with flattened epithelial cells (score 3). (B) In the lumen of this DT, crystals that are smaller than the tubular lumen are clearly visible and located at the luminal side of the injured/regenerating flattened epithelium. Magnification, $\times 1000$.

capsules. After $1 \mathrm{~d}$, HA expression in EG-treated rats was comparable to controls (Figure 9). After 4 and 8 d, however, HA was upregulated in a focal pattern throughout the cortex and OSOM of EG-treated rats (Figure 9), primarily in the interstitium but also at the luminal membrane of tubular cells (Figure 10A). Strikingly, in the majority of cases, crystals were found at the luminal surface of HA-expressing cells (Figure $10 \mathrm{~A})$.

OPN was expressed in a limited number of distal tubular epithelial cells of control rats. After $1 \mathrm{~d}$ of EG, OPN expression was not different from controls, except for a small increase in the OSOM of the moderate-dose EG group (Figure 9). At days 4 and 8 , however, OPN was significantly upregulated in the kidneys of EG-treated rats (Figure 9). Both PT and DT showed a rise in OPN immunostaining (Figure 10, B and C). The classical OPN expression pattern was observed, with Golgi apparatus immunostaining in PT and at the apical membrane in DT, allowing differentiation between PT and DT (previously described after renal ischemia/reperfusion) $(19,26)$. Crystals were retained in apical OPN-expressing DT. Crystals were positive for OPN, which was evident by comparison between optical and polarized light microscopy (Figure 10, B and C).

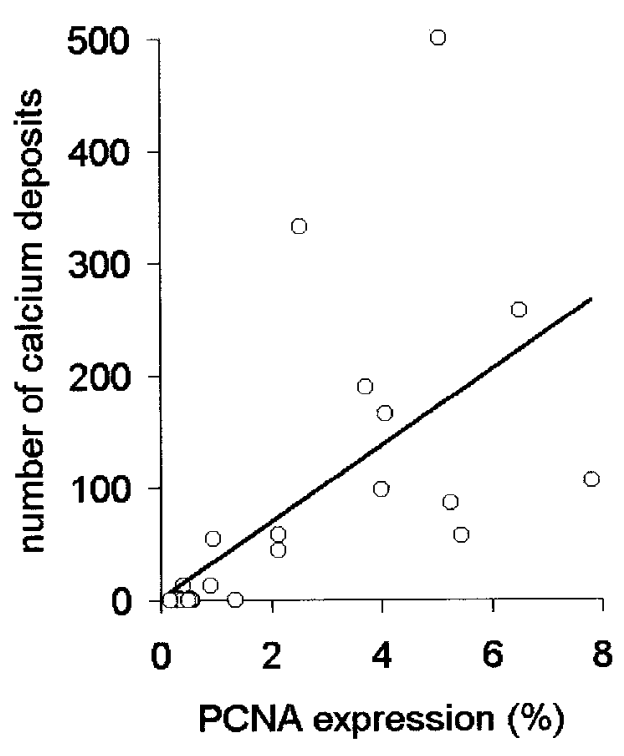

Figure 8. Correlation analysis was performed between the total amount of tubular PCNA expression and the amount of positive von Kossa calcium deposits in sagittal kidney sections of individual rats (Spearman's Rho $=0.819, P<0.0001$ ). 

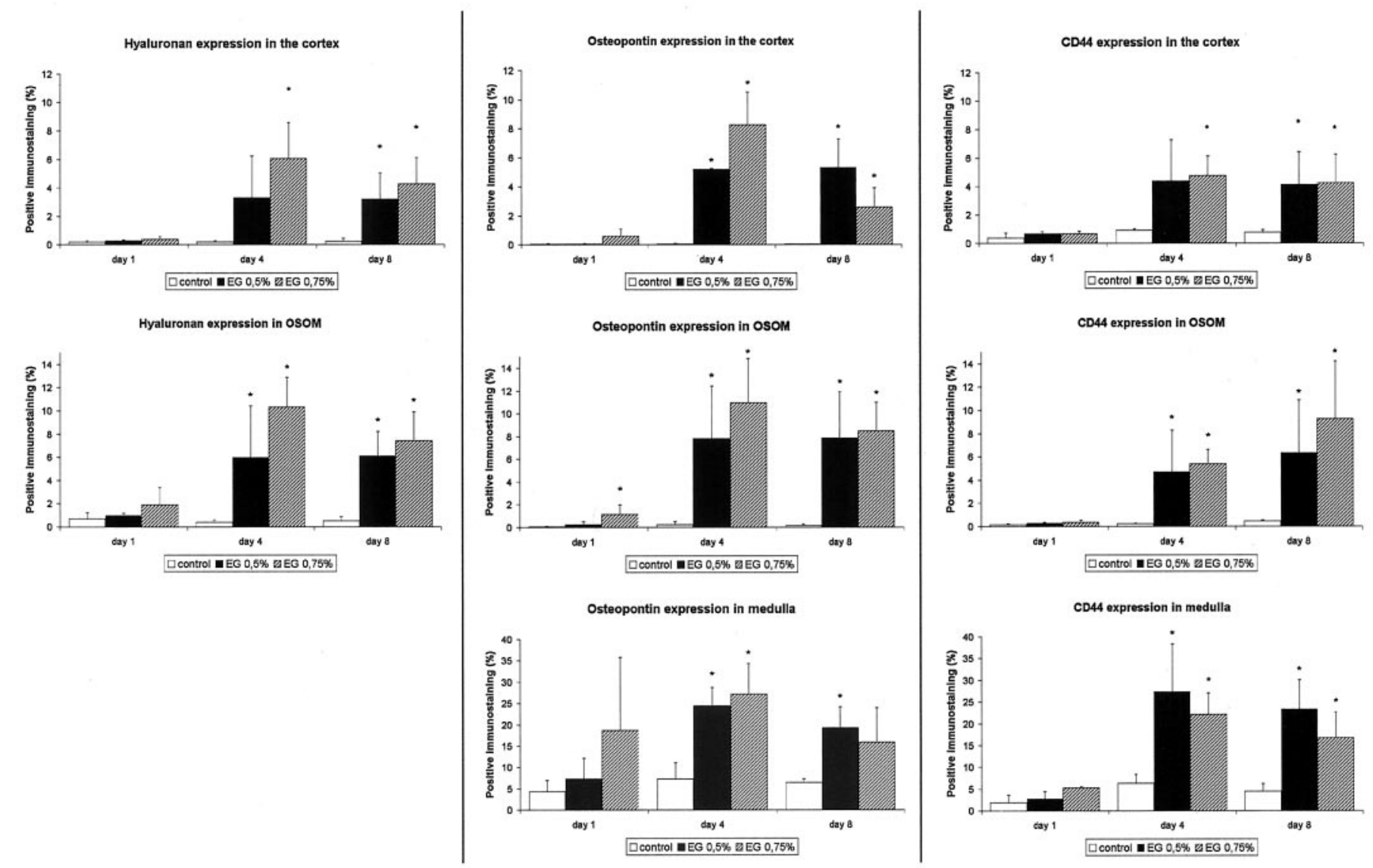

Figure 9. Quantification of renal hyaluronan (HA), osteopontin (OPN), and CD44 expression using computerized image analysis software (KS400). Data are expressed as fractional positive area (\%). Statistical analysis by $t$ test. * Significantly increased compared with controls at the same point in time $(P<0.05)$.

CD44 was hardly expressed in the rat kidney, except for some interstitial cells and glomeruli. After $1 \mathrm{~d}$ of EG, CD44 expression was not significantly different from controls (Figure 9). After 4 and $8 \mathrm{~d}$ of EG, however, CD44 in the cortex, OSOM, and medulla was markedly upregulated (Figure 9). CD44 expression was prominent in a focal pattern along basolateral and apical tubular cell membranes (Figure 10D). Crystals were observed frequently closely at sites where cells expressed CD44 at their luminal membrane (Figure 10D).

\section{Discussion}

In the present study, we investigated the role of HA, OPN, and CD44 in retention of crystals in renal tubules damaged by EG. The EG model is extremely suitable for this purpose since this agent not only is toxic to the nephron but also generates urinary $\mathrm{CaOx}$ crystals $(25,27-30)$. For investigating the earliest events involved in crystal retention, these studies were performed shortly $(1,4$, and $8 \mathrm{~d})$ after the addition of EG to the drinking water and at relatively low concentrations to avoid massive tissue damage. One of the major findings was that there is no crystal retention in the absence of tubular injury/ regeneration but that crystals are retained as soon as renal tubules are injured/regenerating. Crystals were found adhered to the luminal surface of HA-, OPN-, and CD44-expressing injured/regenerating cells. The results of this study therefore strongly suggest that crystal retention in the kidney requires tubular epithelial injury accompanied by luminal expression of HA, OPN, and CD44.

$\mathrm{EG}$, which itself is not nephrotoxic, is metabolized in the liver to several intermediates, including glycoaldehyde, glycolate, glyoxylate, and oxalate (27). It is still a matter of debate which of these metabolites are responsible for the damage to renal tubular cells $(28,29)$. Oxalate precipitates as $\mathrm{CaOx}$ in the primary urine as a result of its poor solubility. The nephrotoxic effect of EG has also been attributed to these crystals $(25,31)$. However, autopsy and renal biopsy studies in humans did not support the concept that crystals are the primary cause of EG toxicity (27). Considering this controversy, it is impossible in the present study to distinguish between crystals binding to injured/regenerating cells and the alternative explanation that crystal deposition causes cell injury (and consequently cells bind crystals). Crystals did not seem to be retained because of their size, because no crystal aggregates occluding the tubular lumen were observed, but crystals were generally smaller (Figures 4, C and D, 7, A and B, and 10, A, B, C, and D).

In urolithiasis research, animals are usually treated with relatively high concentrations of EG for several weeks $(25,30,31)$. Also in these studies, crystals are retained in tu- 

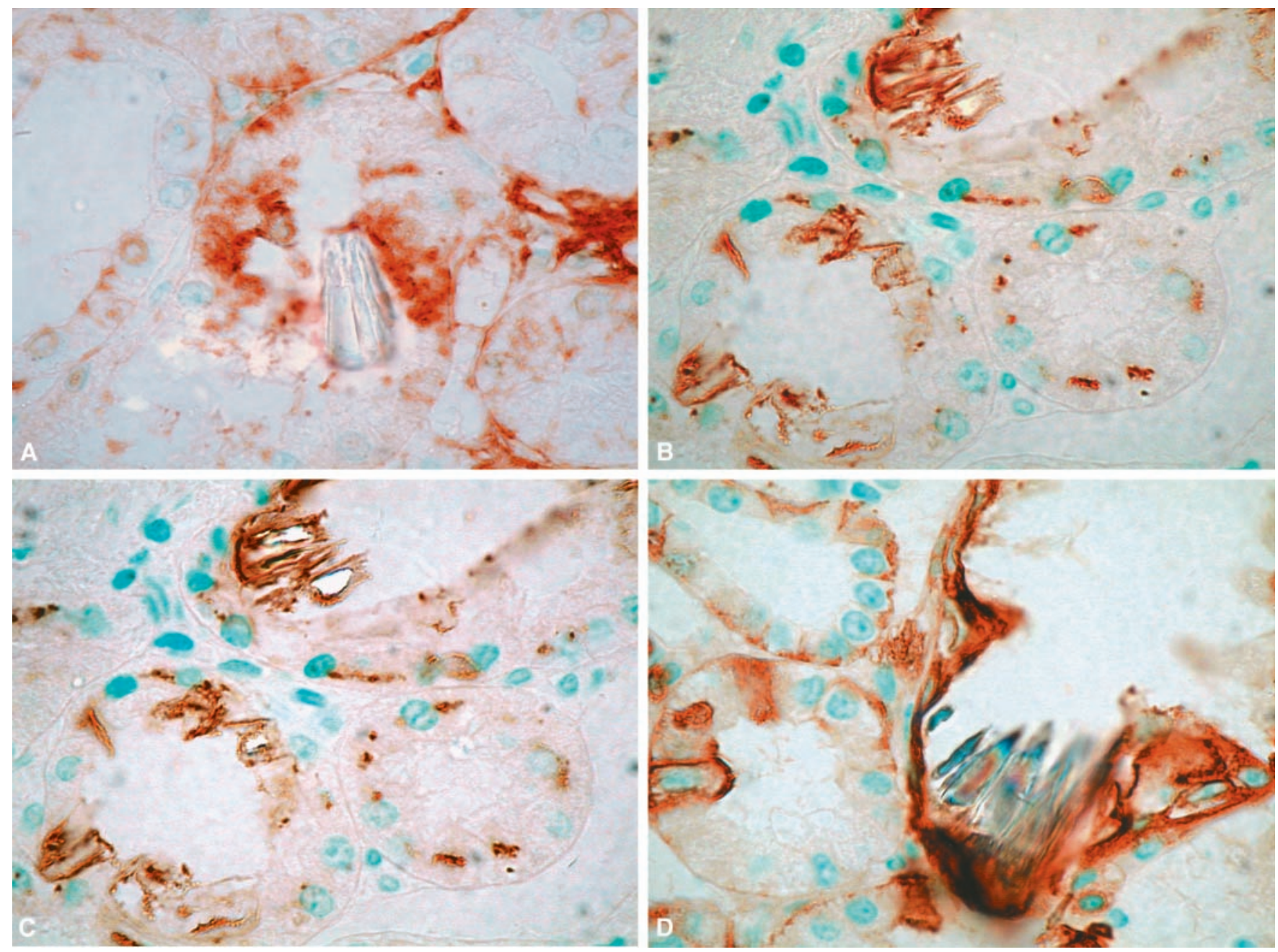

Figure 10. (A) The outer stripe of the outer medulla (OSOM) stained for HA of a rat with $0.75 \%$ EG in the drinking water for 8 d. HA is upregulated in the interstitium as well as at the apical membrane of tubular epithelial cells. A crystal is shown close to cells that express HA at their luminal membrane. (B and C) The OSOM stained for OPN after $8 \mathrm{~d}$ of $0.75 \%$ EG, showing increased typical Golgi apparatus immunostaining in PT and at the apical cell membrane in DT. (C) Crystals visualized with polarized light microscopy. Retained crystals stained for OPN are smaller than the tubular lumen and closely associated with apical OPN-expressing epithelium. (D) The cortex stained for CD44 after $8 \mathrm{~d}$ of $0.75 \%$ EG. CD44 is upregulated at basolateral and apical tubular cell membranes. Polarized light microscopy shows birefringent crystals in the lumen of a tubule closely associated with the surface of flattened cells positive for CD44. Magnification, $\times 1000$.

bules that are clearly injured $(25,31,32)$. In the present study, the short period of treatment ( 1 to $8 \mathrm{~d}$ ) with relatively low concentrations of EG did not result in frank necrosis or cast formation but in a mild form of injury/regeneration. Renal tubular injury was morphologically scored (see Table 1), and PCNA was used to assess cell proliferation. PCNA is an auxiliary protein for DNA polymerase $\delta$ and required for both DNA replication and DNA repair. In proliferating cells, it is upregulated in cell nuclei mainly during the S-phase (DNA synthesis phase) of the cell cycle (33). Consequently, it is widely used as a marker for proliferating cells. Immunohistochemical PCNA staining is a validated method for evaluating epithelial regeneration of the kidney after renal damage (23). It is well known that in the kidney, tubular cell injury and regeneration occur concurrently (23). Hence, the flattened, PCNA-positive tubular cells after 4 and $8 \mathrm{~d}$ of EG treatment (Figure 4B) are dedifferentiated proliferating cells.
HA is a high molecular mass polysaccharide found in many tissues, where it performs a great range of biologic functions $(34,35)$. In the kidney, HA is normally not expressed at the luminal surface of tubular cells and is present only in the medullary interstitium, where it provides structural stability to the tubules and contributes to concentrating the urine (12). HA expression in the renal cortex is upregulated in renal inflammatory diseases such as interstitial nephritis (13), acute ischemic injury $(14,17)$, autoimmune renal injury $(15)$, and acutely rejecting human kidney grafts (16). HA accumulates in wounded tissue shortly after injury to form loose hydrated matrices that allow cell division and migration $(36,37)$. During recent years, we searched extensively for crystal-binding molecules at the surface of renal tubular cells in culture $(10,11,38,39)$. HA was identified as major crystal-binding substance, based on the following results: (1) crystals bind to HA-expressing cells at subconfluence but not to cells in con- 


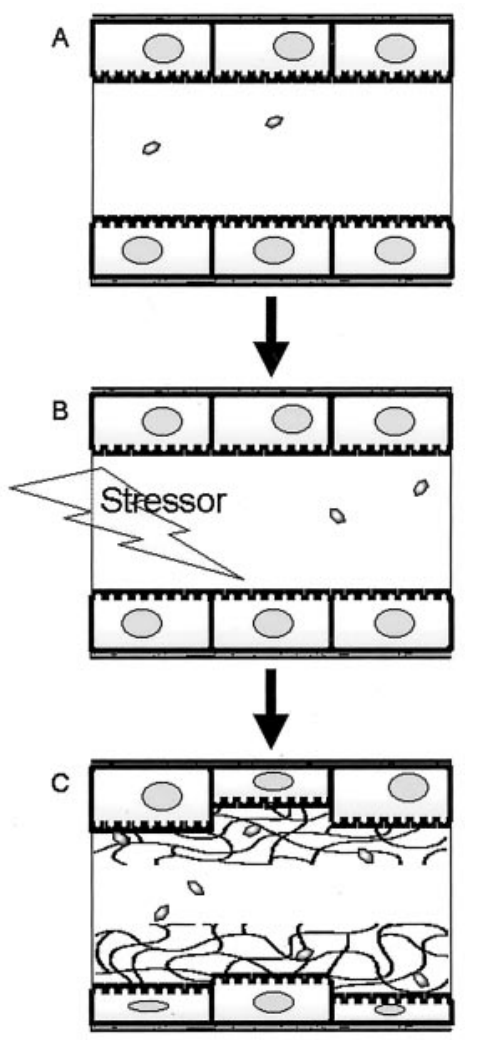

Figure 11. Paradigm of crystal retention. A schematic representation of a cross-section of a distal tubule is shown. (A) Under normal conditions, crystals do not bind to renal tubular epithelial cells and are harmlessly excreted in the urine. (B) Crystal retention is preceded by a stressor injuring the epithelium. (C) During the process of tubular epithelial regeneration and repair, flattened epithelial cells express HA, OPN, and CD44 at their apical membrane. HA is a cell surface crystal-binding molecule. Because these regenerating dedifferentiated tubular epithelial cells are susceptible to crystal binding, crystal retention may ensue.

fluent cultures that do no longer express HA; (2) metabolic labeling studies showed that the surface of proliferating cells contains substantially higher levels of radiolabeled HA; (3) crystal binding could be decreased by Streptomyces hyaluronidase, an enzyme that specifically digests HA; and (4) during wound healing, HA-binding protein binds to migrating and proliferating flattened cells in damaged areas but not to cells in intact monolayers (10). The co-localization of intraluminal $\mathrm{CaOx}$ crystals with HA-expressing tubular cells in the present study suggests for the first time, to our knowledge, a role for $\mathrm{HA}$ in crystal retention in vivo.

The glycoprotein OPN is widely distributed in the body and has been implicated in several physiologic and pathologic processes, including cell adhesion, migration, signaling, inflammation, and biomineralization $(18,40,41)$. In the kidney, the expression of OPN is upregulated during renal injury $(18,19,42)$, including induced by EG (31). The role of OPN under these circumstances is unclear, but OPN seems to be involved in mediating macrophage accumulation and interstitial fibrosis $(18,43)$. The role of OPN in urolithiasis is contro- versial. OPN has been proposed as an inhibitor of crystal formation and retention but also as a promoter of crystal retention (44-46). Recently, crystal retention was studied in OPN knockout and wild-type mice treated with EG (44). Noticeably, after 4 wk of treatment with $1 \%$ EG, no crystals were retained in wild-type mice, whereas some crystal retention was observed in the kidneys of OPN knockouts $(14.3 \pm 3$ von Kossa signals per sagittal kidney section). From these observations, the authors concluded that OPN protects the kidney from crystal formation and retention. However, the crystal retention inhibitor function of OPN seems to be ineffective in the present study, because crystals covered with OPN but smaller in size than the tubular lumen became firmly associated with the cell surface (Figure 10, B and C). This is in agreement with a previous study, in which it was demonstrated that urinary inhibitors of crystallization were unable to prevent the attachment of crystals to regenerating renal tubular cells (47). Consequently, possibly because of the differences in species and study designs between the present study and the one performed by Wesson et al. (44), the role of OPN remains controversial.

CD44 is a ubiquitous transmembrane glycoprotein that is involved in many processes including inflammation (48). CD44 serves as cell surface receptor for both HA and OPN $(21,22)$. In fact, the biologic activity of HA and OPN predominantly depends on their interaction with CD44 (49-51). In the kidney, the expression of CD44 is highly upregulated during various renal disease states $(13,14)$. Hence, it is not surprising that an upregulated expression of CD44 in the renal tubules is accompanied by an increased expression of its ligands HA and OPN. Reports of the role of CD44 in renal stone formation are scarce. In cell culture, it was found that CD44 is expressed at the luminal surface of crystal-binding renal tubular cells but not on that of cells without affinity for crystals (11). In the present study, crystals were also retained at sites where cells expressed CD44. In our opinion, crystals are not likely to become associated with CD44 but rather with HA and/or OPN.

The present study supports in vivo for the first time the concept that crystal retention is associated with HA expressed at the luminal surface of injured/regenerating cells. However, we cannot rule out the importance of other crystal-binding molecules, including sialic acid-containing glycoproteins (52), phosphatidyl serine (53), collagen (54), and nucleolin-related protein (55). Furthermore, several other macromolecules have been implicated in $\mathrm{CaOx}$ crystallization and retention (56), including inter- $\alpha$ inhibitor-related proteins (32) such as bikunin (57) and prothrombin fragment 1 (58). Although in the present study we focused on HA, OPN, and CD44, the interrelationship between these and other molecules as part of complex cell biologic pathways in the pathophysiology of kidney stone disease remains to be determined (2).

Although the expression of HA, OPN, and CD44 by injured/ regenerating tubular epithelial cells most likely is aimed to reestablishment of the epithelial barrier integrity and restoration of renal function, a negative side effect could be that it turns a non-crystal-binding epithelium into a crystal-binding one, thereby setting the stage for crystal retention (Figure 11). 
The clinical relevance of this concept was recently reinforced by observations in kidneys of preterm neonates, in which the development of nephrocalcinosis is common, showing that HA and OPN are abundantly expressed at the luminal membrane of proliferating tubular cells (unpublished results).

In conclusion, the results obtained in this study support the concept that the expression of HA, OPN, and CD44 by injured/ regenerating tubular cells is a prerequisite for retention of crystals in the kidney.

\section{Acknowledgments}

This study was supported by the Oxalosis and Hyperoxaluria Foundation (Grant No. 2749036).

We express our gratitude to Dr. C.M. Giachelli (University of Washington, Seattle, WA) for the generous gift of the OP189 antiserum. We thank Simonne Dauwe for excellent technical assistance, as well as the biochemistry laboratory of the Antwerp University Hospital (Dr. V. van Hoof and C. Verstraten). We thank Frank van der Panne and Dirk de Weerdt for contribution of the photographs.

\section{References}

1. Finlayson B, Reid F: The expectation of free and fixed particles in urinary stone disease. Invest Urol 15: 442-448, 1978

2. Asselman M, Verkoelen CF: Crystal-cell interaction in the pathogenesis of kidney stone disease. Curr Opin Urol 12: 271-276, 2002

3. King JS Jr: Etiologic factors involved in urolithiasis: A review of recent research. J Urol 97: 583-591, 1967

4. Khan SR, Shevock PN, Hackett RL: Acute hyperoxaluria, renal injury and calcium oxalate urolithiasis. J Urol 147: 226-230, 1992

5. Mandel N: Mechanism of stone formation. Semin Nephrol 16: 364-374, 1996

6. Baggio B, Gambaro G, Ossi E, Favaro S, Borsatti A: Increased urinary excretion of renal enzymes in idiopathic calcium oxalate nephrolithiasis. J Urol 129: 1161-1162, 1983

7. Kumar S, Sigmon D, Miller T, Carpenter B, Khan S, Malhotra R, Scheid C, Menon M: A new model of nephrolithiasis involving tubular dysfunction/injury. J Urol 146: 1384-1389, 1991

8. Verkoelen CF, van der Boom BG, Kok DJ, Houtsmuller AB, Visser P, Schroder FH, Romijn JC: Cell type-specific acquired protection from crystal adherence by renal tubule cells in culture. Kidney Int 55: 1426-1433, 1999

9. Verkoelen CF, van der Boom BG, Houtsmuller AB, Schroder FH, Romijn JC: Increased calcium oxalate monohydrate crystal binding to injured renal tubular epithelial cells in culture. Am J Physiol 274: F958-F965, 1998

10. Verkoelen CF, Van Der Boom BG, Romijn JC: Identification of hyaluronan as a crystal-binding molecule at the surface of migrating and proliferating MDCK cells. Kidney Int 58: 10451054,2000

11. Verhulst A, Asselman M, Persy VP, Schepers MS, Helbert MF, Verkoelen CF, De Broe ME: Crystal retention capacity of cells in the human nephron: Involvement of CD44 and its ligands hyaluronic acid and osteopontin in the transition of a crystal bindinginto a nonadherent epithelium. J Am Soc Nephrol 14: 107-115, 2003

12. Knepper MA, Saidel GM, Hascall VC, Dwyer T: Concentration of solutes in the renal inner medulla: Interstitial hyaluronan as a mechano-osmotic transducer. Am J Physiol Renal Physiol 284: F433-F446, 2003

13. Sibalic V, Fan X, Loffing J, Wuthrich RP: Upregulated renal tubular CD44, hyaluronan, and osteopontin in kdkd mice with interstitial nephritis. Nephrol Dial Transplant 12: 1344-1353, 1997

14. Lewington AJ, Padanilam BJ, Martin DR, Hammerman MR: Expression of CD44 in kidney after acute ischemic injury in rats. Am J Physiol Regul Integr Comp Physiol 278: R247-R254, 2000

15. Feusi E, Sun L, Sibalic A, Beck-Schimmer B, Oertli B, Wuthrich RP: Enhanced hyaluronan synthesis in the MRL-Fas(lpr) kidney: Role of cytokines. Nephron 83: 66-73, 1999

16. Wells A, Larsson E, Hanas E, Laurent T, Hallgren R, Tufveson G: Increased hyaluronan in acutely rejecting human kidney grafts. Transplantation 55: 1346-1349, 1993

17. Johnsson C, Tufveson G, Wahlberg J, Hallgren R: Experimentally-induced warm renal ischemia induces cortical accumulation of hyaluronan in the kidney. Kidney Int 50: 1224-1229, 1996

18. Xie Y, Sakatsume M, Nishi S, Narita I, Arakawa M, Gejyo F: Expression, roles, receptors, and regulation of osteopontin in the kidney. Kidney Int 60: 1645-1657, 2001

19. Persy VP, Verstrepen WA, Ysebaert DK, De Greef KE, De Broe ME: Differences in osteopontin up-regulation between proximal and distal tubules after renal ischemia/reperfusion. Kidney Int 56: 601-611, 1999

20. Xie $\mathrm{Y}$, Nishi S, Iguchi S, Imai N, Sakatsume M, Saito A, Ikegame M, Iino N, Shimada H, Ueno M, Kawashima H, Arakawa M, Gejyo F: Expression of osteopontin in gentamicininduced acute tubular necrosis and its recovery process. Kidney Int 59: 959-974, 2001

21. Aruffo A, Stamenkovic I, Melnick M, Underhill CB, Seed B: CD44 is the principal cell surface receptor for hyaluronate. Cell 61: 1303-1313, 1990

22. Weber GF, Ashkar S, Glimcher MJ, Cantor H: Receptor-ligand interaction between CD44 and osteopontin (Eta-1). Science 271: 509-512, 1996

23. Nouwen EJ, Verstrepen WA, Buyssens N, Zhu MQ, De Broe ME: Hyperplasia, hypertrophy, and phenotypic alterations in the distal nephron after acute proximal tubular injury in the rat. $L a b$ Invest 70: 479-493, 1994

24. Hewlett TP, Jacobsen D, Collins TD, McMartin KE: Ethylene glycol and glycolate kinetics in rats and dogs. Vet Hum Toxicol 31: 116-120, 1989

25. Khan SR: Animal model of calcium oxalate nephrolithiasis. In: Calcium Oxalate in Biological Systems, edited by Khan SR, Boca Raton, CRC Press, 1995, pp 343-359

26. Verhulst A, Persy VP, Van Rompay AR, Verstrepen WA, Helbert MF, De Broe ME: Osteopontin synthesis and localization along the human nephron. J Am Soc Nephrol 13: 1210-1218, 2002

27. Schrier RW: Ethylene glycol toxicity. In: Diseases of the Kidney and Urinary Tract, 7th ed., Philadelphia, Lippincott, Williams \& Wilkins 2001, pp 1316-1326

28. Poldelski V, Johnson A, Wright S, Rosa VD, Zager RA: Ethylene glycol-mediated tubular injury: Identification of critical metabolites and injury pathways. Am J Kidney Dis 38: 339-348, 2001

29. Roberts JA, Seibold HR: Ethylene glycol toxicity in the monkey. Toxicol Appl Pharmacol 15: 624-631, 1969

30. Lyon ES, Borden TA, Vermeulen CW: Experimental oxalate lithiasis produced with ethylene glycol. Invest Urol 4: 143-151, 1966 
31. Khan SR, Johnson JM, Peck AB, Cornelius JG, Glenton PA: Expression of osteopontin in rat kidneys: Induction during ethylene glycol induced calcium oxalate nephrolithiasis. J Urol 168: 1173-1181, 2002

32. Moriyama MT, Glenton PA, Khan SR: Expression of inter-alpha inhibitor related proteins in kidneys and urine of hyperoxaluric rats. J Urol 165: 1687-1692, 2001

33. Kelman Z: PCNA: Structure, functions and interactions. Oncogene 14: 629-640, 1997

34. Tammi MI, Day AJ, Turley EA: Hyaluronan and homeostasis: A balancing act. J Biol Chem 277: 4581-4584, 2002

35. Toole BP, Wight TN, Tammi MI: Hyaluronan-cell interactions in cancer and vascular disease. J Biol Chem 277: 4593-4596, 2002

36. Noble PW: Hyaluronan and its catabolic products in tissue injury and repair. Matrix Biol 21: 25-29, 2002

37. Chen WY, Grant ME, Schor AM, Schor SL: Differences between adult and foetal fibroblasts in the regulation of hyaluronate synthesis: Correlation with migratory activity. J Cell Sci 94: 577-584, 1989

38. Verkoelen CF, Van Der Boom BG, Kok DJ, Schroder FH, Romijn JC: Attachment sites for particles in the urinary tract. J Am Soc Nephrol 10[Suppl 14]: S430-S435, 1999

39. Verkoelen CF, van der Boom BG, Kok DJ, Romijn JC: Sialic acid and crystal binding. Kidney Int 57: 1072-1082, 2000

40. Hudkins KL, Giachelli CM, Cui Y, Couser WG, Johnson RJ, Alpers CE: Osteopontin expression in fetal and mature human kidney. J Am Soc Nephrol 10: 444-457, 1999

41. Mazzali M, Kipari T, Ophascharoensuk V, Wesson JA, Johnson $\mathrm{R}$, Hughes J: Osteopontin-A molecule for all seasons. QJM 95: 3-13, 2002

42. Denhardt DT, Noda M, O'Regan AW, Pavlin D, Berman JS: Osteopontin as a means to cope with environmental insults: Regulation of inflammation, tissue remodeling, and cell survival. J Clin Invest 107: 1055-1061, 2001

43. Persy VP, Verhulst A, Ysebaert DK, De Greef KE, De Broe ME: Reduced postischemic macrophage infiltration and interstitial fibrosis in osteopontin knockout mice. Kidney Int 63: 543-553, 2003

44. Wesson JA, Johnson RJ, Mazzali M, Beshensky AM, Stietz S, Giachelli C, Liaw L, Alpers CE, Couser WG, Kleinman JG, Hughes $\mathrm{J}$ : Osteopontin is a critical inhibitor of calcium oxalate crystal formation and retention in renal tubules. J Am Soc Nephrol 14: 139-147, 2003

45. Yamate T, Kohri K, Umekawa T, Iguchi M, Kurita T: Osteopontin antisense oligonucleotide inhibits adhesion of calcium oxalate crystals in Madin-Darby canine kidney cell. J Urol 160: 15061512, 1998
46. Lieske JC, Hammes MS, Hoyer JR, Toback FG: Renal cell osteopontin production is stimulated by calcium oxalate monohydrate crystals. Kidney Int 51: 679-686, 1997

47. Schepers MS, van der Boom BG, Romijn JC, Schroder FH, Verkoelen CF: Urinary crystallization inhibitors do not prevent crystal binding. J Urol 167: 1844-1847, 2002

48. Pure E, Cuff CA: A crucial role for CD44 in inflammation. Trends Mol Med 7: 213-221, 2001

49. Lesley J, Hyman R, English N, Catterall JB, Turner GA: CD44 in inflammation and metastasis. Glycoconj J 14: 611-622, 1997

50. Lesley J, English NM, Gal I, Mikecz K, Day AJ, Hyman R: Hyaluronan binding properties of a CD44 chimera containing the link module of TSG-6. J Biol Chem 277: 26600-26608, 2002

51. Zohar R, Suzuki N, Suzuki K, Arora P, Glogauer M, McCulloch CA, Sodek J: Intracellular osteopontin is an integral component of the CD44-ERM complex involved in cell migration. J Cell Physiol 184: 118-130, 2000

52. Lieske JC, Leonard R, Swift H, Toback FG: Adhesion of calcium oxalate monohydrate crystals to anionic sites on the surface of renal epithelial cells. Am J Physiol 270: F192-F199, 1996

53. Wiessner JH, Hasegawa AT, Hung LY, Mandel NS: Oxalateinduced exposure of phosphatidylserine on the surface of renal epithelial cells in culture. J Am Soc Nephrol 10[Suppl 14]: S441-S445, 1999

54. Kohri K, Kodama M, Ishikawa Y, Katayama Y, Matsuda H, Imanishi M, Takada M, Katoh Y, Kataoka K, Akiyama T, et al.: Immunofluorescent study on the interaction between collagen and calcium oxalate crystals in the renal tubules. Eur Urol 19: 249-252, 1991

55. Sorokina EA, Kleinman JG: Cloning and preliminary characterization of a calcium-binding protein closely related to nucleolin on the apical surface of inner medullary collecting duct cells. J Biol Chem 274: 27491-27496, 1999

56. Wesson JA, Worcester EM, Wiessner JH, Mandel NS, Kleinman JG: Control of calcium oxalate crystal structure and cell adherence by urinary macromolecules. Kidney Int 53: $952-$ 957, 1998

57. Iida S, Peck AB, Byer KJ, Khan SR: Expression of bikunin mRNA in renal epithelial cells after oxalate exposure. J Urol 162: 1480-1486, 1999

58. Nishio S, Hatanaka M, Takeda H, Iseda T, Iwata H, Yokoyama M: Analysis of urinary concentrations of calcium phosphate crystal-associated proteins: $\alpha 2$-HS-glycoprotein, prothrombin F1, and osteopontin. J Am Soc Nephrol 10[Suppl 14]: S394S396, 1999 